\title{
Minor Actinide \\ Separations Using Ion Exchangers or lonic Liquids
}

Fuel Cycle Research \& Development

Prepared for

U.S. Department of Energy Sigma Team for Minor Actinide Separations

D. T. Hobbs, A. Clearfield, A. E. Visser, \& N. J. Bridges

Savannah River National Laboratory September 20, 2011 FCRD-SWF-2011-000276

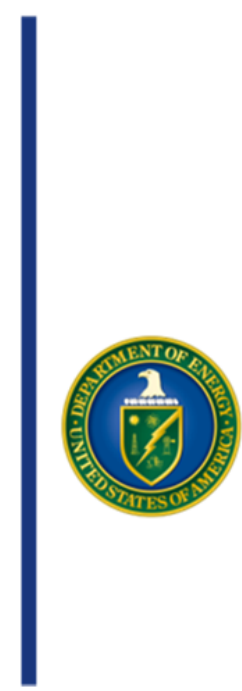


Minor Actinide Separations Using Ion Exchangers or Ionic Liquids

September 2011

\section{DISCLAIMER}

This information was prepared as an account of work sponsored by an agency of the U.S. Government. Neither the U.S. Government nor any agency thereof, nor any of their employees, makes any warranty,

expressed or implied, or assumes any legal liability or responsibility for the accuracy, completeness, or usefulness, of any information, apparatus, product, or process disclosed, or represents that its use would not infringe privately owned rights. References herein to any specific commercial product, process, or service by trade name, trade mark, manufacturer, or otherwise, does not necessarily constitute or imply its endorsement, recommendation, or favoring by the U.S. Government or any agency thereof. The views and opinions of authors expressed herein do not necessarily state or reflect those of the U.S. Government or any agency thereof. 


\section{Reviews and Approvals}

D. T. Hobbs, Co-author, Separations and Actinide Science Programs, SRNL Date

A. Clearfield, Co-author, Texas A\&M University

Date

N. J. Bridges, Co-author, Separations and Actinide Science Programs, SRNL Date

A. E. Visser, Co-author, Separations and Actinide Science Programs, SRNL Date

K. M. Taylor-Pashow, Technical Reviewer, SRNL

Date

Separations and Actinide Science Programs

S. D. Fink, Manager, Separations and Actinide Science Programs, SRNL Date

S. L. Marra, Manager, E\&CP Research Programs, SRNL

Date 


\section{SUMMARY}

This project seeks to determine if (1) inorganic-based ion exchange materials or (2) electrochemical methods in ionic liquids can be exploited to provide effective Am and $\mathrm{Cm}$ separations. Specifically, we seek to understand the fundamental structural and chemical factors responsible for the selectivity of inorganic-based ion-exchange materials for actinide and lanthanide ions. Furthermore, we seek to determine whether ionic liquids can serve as the electrolyte that would enable formation of higher oxidation states of Am and other actinides.

Experiments indicated that $\mathrm{pH}$, presence of complexants and Am oxidation state exhibit significant influence on the uptake of actinides and lanthanides by layered sodium titanate and hybrid zirconium and tin phosphonate ion exchangers. The affinity of the ion exchangers increased with increasing $\mathrm{pH}$. Greater selectivity among $\mathrm{Ln}(\mathrm{III})$ ions with sodium titanate materials occurs at a $\mathrm{pH}$ close to the isoelectric potential of the ion exchanger. The addition of DTPA decreased uptake of Am and Ln, whereas the addition of TPEN generally increases uptake of Am and Ln ions by sodium titanate.

Testing confirmed two different methods for producing Am(IV) by oxidation of Am(III) in ionic liquids (ILs). Experimental results suggest that the unique coordination environment of ionic liquids inhibits the direct electrochemical oxidation of Am(III). The non-coordinating environment increases the oxidation potential to a higher value, while making it difficult to remove the inner coordination of water. Both confirmed cases of Am(IV) were from the in-situ formation of strong chemical oxidizers. 


\section{ACRONYMS}

$\left[\mathrm{C}_{4} \mathrm{mim}\right]\left[\mathrm{NTf}_{2}\right] \quad$ 1-butyl-3-methylimidazolium

bis(trifluoromethylsulfonyl)imide

$\left[\mathrm{C}_{4} \mathrm{mim}\right][$ Ace $] \quad$ 1-butyl-3-methylimidazolium acetate

$\left[\mathrm{N}_{4111}\right]\left[\mathrm{NTf}_{2}\right] \quad$ butyltrimethylammonium bis(trifluoromethylsulfonyl)imide

CST

crystalline silicotitanate

IEC ion exchange capacity

IEP isoelectric point

ILs ionic liquids

$\mathrm{FeCp}_{2}$

ferrocene

FCR\&D

Fuel Cycle Research and Development

$K_{d}$

distribution factor

MST

monosodium titanate

$\mathrm{SF}$

separation factor

SRNL

Savannah River National Laboratory

SNT

sodium nonatitanate

TAMU

Texas A\&M University

TSP

titanosilicate having the pharmacosiderite structure

$\mathrm{UV}-\mathrm{V}$ is

ultraviolet-visible 


\section{SEPARATIONS}

\section{INTRODUCTION}

Our research project seeks to determine if minor actinide separations can be accomplished effectively using (1) inorganic-based ion exchange materials or (2) by an electrochemical method employing ionic liquids (ILs). Over the last two decades a number of inorganic-based ion exchange materials have been developed with high selectivity for radiochemical species in strongly alkaline environments. We postulate that selectivities for minor actinides can be tailored in inorganic materials for separations under strongly acidic environments. Thus, we seek to understand the fundamental structural and chemical factors responsible for the selectivity of inorganic-based ion exchange materials for actinide and lanthanide ions. The basis of our hypothesis of ionic liquid-based separations is the ability of ILs to act not only as electrolytes, but also as stabilizing solvents for higher oxidation states of Am, such as $A m(V)$ and Am(VI). Through the investigation of Am electrochemistry in ILs, a better fundamental understanding of the chemical potentials of Am in a select number of ILs will be compared versus the oxidized species of Am.

\section{SIGNIFICANCE}

Inorganic ion exchange materials generally exhibit much greater radiation and chemical stability than organic-based ion exchange materials. Consequently, these materials may be used in much higher radiation environments compared to organic-based materials. This may be a significant advantage in developing effective separations in feed streams in which $\mathrm{Cs}$ and $\mathrm{Sr}$ have not been previously separated. Ion exchange separations can be easily deployed in continuous and semicontinuous modes at a variety of scales. Thus, there is considerable flexibility in deploying the separation technology. Depending on the framework of the ion exchange material, the material may serve also as a final waste form matrix for the disposal of the separated radioisotopes.

The separation of $\mathrm{Am}$ and $\mathrm{Cm}$ is difficult using current liquid/liquid extraction technology. In aqueous solutions, Am and $\mathrm{Cm}$ have relatively similar chemistry; both are stable only in the +3 oxidation state in aqueous solutions, and comparable charge to size ratios limit the discriminating driving forces commonly used in liquid extraction. Inorganic ion exchange materials generally have much more rigid frameworks and coordination sites than those of the organic-based extractants employed in solvent extraction processes. This increased rigidity may amplify the ability to discriminate based on the slight size differences between the trivalent cations (i.e., Am and $\mathrm{Cm}$ ) compared to the more flexible coordination environments of the organic extractants. ILs provide an electrochemical medium in which higher oxidation states of Am (i.e., IV, V, and VI) can be achieved electrochemically while also allowing the ILs to provide a stabilizing matrix. This use of a non-traditional solvent and a non-traditional approach can provide a gateway for new methods to separate Am from Cm.

\section{APPROACH}

Ion Exchange Separations

Inorganic ion exchangers have found considerable use in the purification of wastewaters and some rudimentary theories to explain metal ion selectivity have been proposed. ${ }^{1,2}$ In contrast, inorganic ion exchangers have not been used to any great extent in actinide and lanthanide separations. Therefore, it is a priori not possible to predict what can be accomplished by their use. A number of titanium based materials have been developed over the last three decades that 
exhibit high affinities for cesium, strontium and actinides under strongly alkaline conditions. ${ }^{3,4}$ More recently, it was discovered that introduction of a peroxotitanate group significantly decreased the affinity of the layered titanates to exchange $\mathrm{UO}_{2}{ }^{2+}$ while increasing affinities for $\mathrm{Pu}^{4+}$ and $\mathrm{NpO}_{2}^{+5}$ Thus, there is evidence that structural modifications to inorganic ion exchangers can lead to enhanced selectivity for the exchange of actinides.

Using this information as a guide, we chose several different types of ion exchangers for study including (1) titanates and titanosilicates, (2) mixed metal oxides having the pyrochlore structure and (3) porous hybrid materials in which a metal oxide binds to an organophosphonate group to produce a mixed inorganic and organic ion exchanger. Our approach is to synthesize a variety of exchangers in each group and determine their ion exchange properties and chemical stability in concentrated acid solutions. The focus is to determine the structural factors that maximize americium affinity/selectivity. There are a number of the titanate and titanosilicate group of materials to test. Hybrid materials based on zirconium have been produced and have exhibited selectivity for lanthanides. However, selectivity of the titanates, titanosilicates and zirconium phosphonates for actinides and chemical stability in strongly acidic solutions is not known. Even less is known about the selectivity of pyrochlores. However, these materials are known to have high chemical stability in strong acids.

For those samples that show promise, we will determine the crystal structures, with and without the ions of interest. We can also utilize in situ X-ray techniques to track the sites occupied by the heavy ion as the uptake increases. Our purpose is to assess the effect of charge, ionic radius, hydration of the incoming ions, and the effect of the tunnel size and structure changes brought about by framework substitution to maximize americium affinity/selectivity. In this regard, we know a great deal about crystalline silicotitanate (CST) and pharmacosiderite type compounds, but only with alkali and alkaline earth metals, and their connection to lanthanides and actinides is meager. With the zirconium phosphonate hybrid compounds we do know that they are selective for lanthanides, but almost no work with actinides has been done. Therefore, is incumbent for us to determine the selectivity of these tunnel or cavity type exchangers towards lanthanides and actinides with a view towards group and individual separations.

\section{Electrochemical Separations}

In this work, we propose the separation of Am from $\mathrm{Cm}$ through the use of electrochemical oxidation of Am in IL media paired with a later separation step. Although ILs were originally designed to be a low-temperature molten salt for electrochemical processes, only a limited body of work exists for the investigation of actinide chemistry in ILs. Thus, we initiated fundamental studies to explore electrochemical reactions of Am in IL media.

Our principal analytical techniques for these studies include cyclic voltammetry (CV) and controlled potential electrolysis (CPE). CV allows one to identify electrochemical reactions that occur for both the electrolyte (i.e., ionic liquid) and the analyte (i.e., Am). CPE allows one to perform a single desired electrochemical reaction by applying a constant potential in a cell containing Am and the IL electrolyte. With the installation of new fiber optics in the radiological glovebox, the electrochemical/spectroscopic studies were conducted simultaneously. The addition of the spectroscopic abilities allows for the UV/vis/NIR spectra to be collected and compared to the traditional aqueous based chemistry. 


\subsection{Ion Exchange Studies}

During FY11 we completed batch contact experiments with two sodium titanates (monosodium titanate (MST) and SrTreat ${ }^{\mathbb{B}}$ ) and a series of porous, pillared metal phosphonates of general composition $\mathrm{M}\left(\mathrm{O}_{3} \mathrm{PC}_{6} \mathrm{H}_{4} \mathrm{PO}_{3}\right)_{1-\mathrm{x} / 2}\left(\mathrm{O}_{3} \mathrm{POH}\right)_{\times}$with $\mathrm{M}=\mathrm{Zr}^{4+}, \mathrm{Sn}^{4+}$. These experiments included evaluation of the influence of $\mathrm{pH}$ on $\mathrm{Am}$ and $\mathrm{Ln}^{3+}$ selectivity, encompassing a range of $\mathrm{pH}$ conditions spanning the isoelectric point (IEP) of the titanate sorbents. The use of complexing agents in conjunction with titanate ion exchange materials has been further explored during this fiscal year. A final investigation examined the selectivity of higher oxidation states of Am with selected ion-exchange samples. The higher oxidation state americyl species, $\mathrm{AmO}_{2}{ }^{+}$or $\mathrm{AmO}_{2}{ }^{2+}$, was expected to have a reduced affinity for the ion-exchanger and, therefore, a higher concentration of Am would remain in solution in a batch contact experiment. The opposite proved true.

Under acidic conditions testing indicated that the titanates have relatively high affinity for the $\mathrm{Ln}^{3+}$ and $\mathrm{Am}^{3+}$ with increasing affinity as the $\mathrm{pH}$ increases. The maximum affinity of both titanate ion exchangers occurs at $\mathrm{pH}$ 6. At lower $\mathrm{pH}$ (higher acid concentration), the affinity is greatly reduced suggesting that a low $\mathrm{pH}$ acid solution could serve to elute these ion exchangers after loading $\mathrm{Am}^{3+}$ and $\mathrm{Ln}^{3+}$ ions at a higher $\mathrm{pH}$ condition. Elution experiments will be an area of exploration in FY12. The noticeable difference in SrTreat ${ }^{\circledR}$ vs. MST performance, shown in Figure 1, is related to the isoelectric points of these materials. SrTreat ${ }^{\mathbb{B}}$ performance steadily increases from $\mathrm{pH} 3-6$ and has a higher initial uptake of lanthanides owing to its 2.21 isoelectric point. MST, with an isoelectric point of 4.46 exhibits low and generally stable uptake at $\mathrm{pH} 3-4$ with a slight increase in performance at $\mathrm{pH} 5$ and a maximum at $\mathrm{pH} 6$. Interestingly, the greater range of selectivities among the lanthanides was observed at $\mathrm{pH}$ conditions closest to the IEP of the titanates.

We also tested the effect that the addition of a complexing agent has on the uptake of $\mathrm{Am}^{3+}$ and $\mathrm{Ln}^{3+}$ ions at $\mathrm{pH} 3$ and 5.5 with SrTreat $^{\circledR}$. Complexing agents tested included diethylenetriaminepentaacetic acid (DTPA) and N,N,N',N'-tetrakis(2pyridylmethyl)ethylenediamine (TPEN). With no complexant present, $\mathrm{K}_{\mathrm{d}}$ was 23 and $1545 \mathrm{~mL} / \mathrm{g}$ for $\mathrm{pH} 3$ and 5.5, respectively. Screening tests showed that the addition of DTPA had no effect at $\mathrm{pH} 3$ and significantly reduced the affinity of the ion exchangers to sorb americium at $\mathrm{pH}>5$, resulting in $\mathrm{K}_{\mathrm{d}}$ values of 20 and $61 \mathrm{~mL} / \mathrm{g}$, respectively. The addition of TPEN slightly increased uptake of $\mathrm{Am}^{3+}$ and the $\mathrm{Ln}^{3+}$ ions at $\mathrm{pH} 3$ and had no effect at $\mathrm{pH} 5.5 . \mathrm{K}_{\mathrm{d}}$ in the presence of TPEN was $140 \mathrm{~mL} / \mathrm{g}$ for $\mathrm{Am}^{3+}$ at $\mathrm{pH} 3$ and $1440 \mathrm{~mL} / \mathrm{g}$ at $\mathrm{pH} 5.5$. Uptake values for 10 lanthanides show a similar increase in uptake at $\mathrm{pH} 5.5$ over the system with no complexant present.

We performed an experiment to evaluate the effects of Am oxidation state using sodium bismuthate to oxidize Am(III) to Am(V) or Am(VI). The bismuthate was added to an Am(III)spiked lanthanide stock solution and allowed to contact the system for 30 minutes at room temperature before being added to the SrTreat ${ }^{\circledR}$. At the equilibrium $\mathrm{pH}=5, \mathrm{~K}_{\mathrm{d}}$ was $\sim 450 \mathrm{~mL} / \mathrm{g}$ in the oxidized system as compared to $\sim 200 \mathrm{~mL} / \mathrm{g}$ in the unoxidized system. The higher $\mathrm{K}_{\mathrm{d}}$ value is not unexpected since sodium titanates have exhibited high affinities for high oxidation state metal ions in weakly acidic solutions. ${ }^{6}$

FY11 testing with hybrid ion exchangers focused on zirconium and tin based materials in both the $\mathrm{H}^{+}$and $\mathrm{Na}^{+}$phases. It was found that these hybrid materials have very little affinity towards mono- and di-vialent cations showing $\mathrm{K}_{\mathrm{d}}$ values many orders of magnitude smaller than the trivialent lanthanides (see Table 1). From this it can also be seen that there is a remarkable 
difference in the behavior of the Na-Zr-hybrid from the other three materials, showing much higher $K_{d}$ values in all cases. Neodymium was selected for a more rigorous investigation, because it has been established as a good analog for americium. ${ }^{7,8}$ To probe the reversibility of the Ln sorption the $\mathrm{K}_{\mathrm{d}}$ was tracked as a function of acidity (see Figure 2). The log-log plot shows a linear relationship between the $\mathrm{K}_{\mathrm{d}}$ and acidity with a slope of 2.1, 2.9, and 1.7 for H-Zrhybrid, Na-Zr-hybrid, and both Sn-hybrids respectively. The Na-Zr-hybrid performed better than the others at $\mathrm{pH} 3$, while its steeper slope indicates an ease of reversibility.

To investigate the behavior of these materials toward the actinides, personnel traveled to Carlsbad NM and performed ion affinity studies at Los Alamos National Laboratories-Carlsbad Operations in the Carlsbad Environmental Monitoring \& Research Center. The results for those studies are summarized in Table 2. The concentrations of $\mathrm{NpO}_{2}{ }^{+}, \mathrm{PuO}_{2}{ }^{2+}, \mathrm{Nd}^{3+}$, and $\mathrm{Pu}^{4+}$ were all on the order of $10^{-4} \mathrm{M}$. The range of $\mathrm{K}_{\mathrm{d}}$ values for the $\mathrm{An}(\mathrm{IV}), \mathrm{An}(\mathrm{V})$ and $\mathrm{An}(\mathrm{VI})$ species compared to the $\mathrm{Nd}$ (III) species suggest very good separation factors (SF) can be achieved under dilute acid conditions. FY12 studies will determine separation factors of the An(III) and Ln(III) ions with these materials in dilute nitric acid.

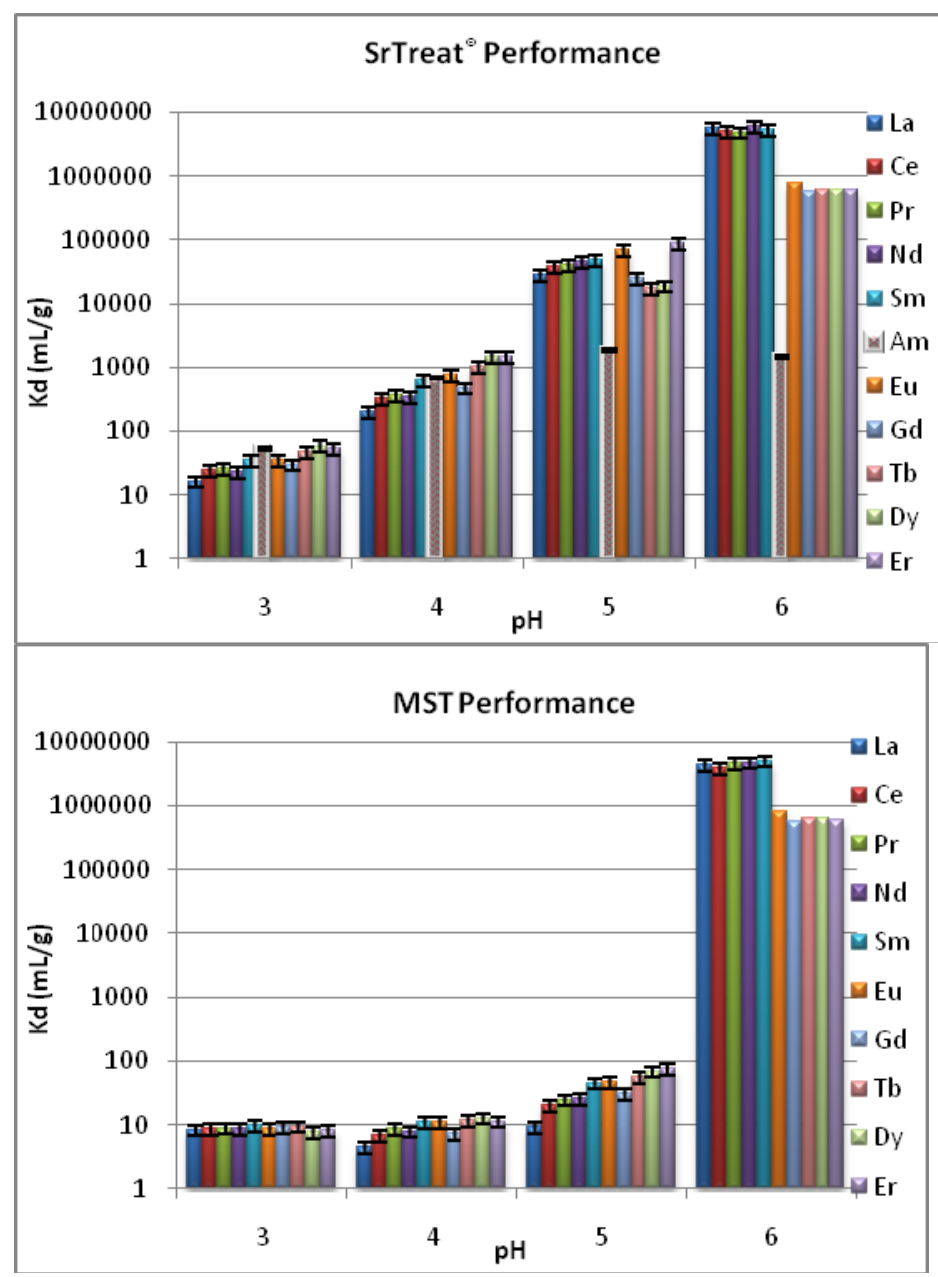

Figure 1. $\mathrm{K}_{\mathrm{d}}$ values for $\mathrm{Ln}^{3+}$ and $\mathrm{Am}^{3+}$ at $\mathrm{pH} 3-6$ upon contact with SrTreat ${ }^{\circledR}$ and MST. $K_{d}$ values for Eu, Gd, Tb, Dy and Er at pH 6 are greater than values since measured concentration fell below quantifiable limits for these lanthanides. 
Table 1: $\mathrm{K}_{\mathrm{d}}$ values (mL/g) of Hybrid Zirconium and Tin Phosphonate Ion Exchangers with Selected Sorbates at pH 3 in $\mathrm{HNO}_{3}$

\begin{tabular}{|c|c|c|c|c|c|c|c|c|}
\hline Sample & $\mathrm{Na}^{+}$ & $\mathrm{Cs}^{+}$ & $\mathrm{Ca}^{2+}$ & $\mathrm{Sr}^{2+}$ & $\mathrm{Nd}^{3+}$ & $\mathrm{Sm}^{3+}$ & $\mathrm{Ho}^{3+}$ & $\mathbf{Y b}^{3^{+}}$ \\
\hline H-Zr-hybrid & $32 \pm 27$ & $450 \pm 30$ & $190 \pm 130$ & $650 \pm 73$ & $29,000 \pm 2,000$ & $80,000 \pm 10,000$ & $110,000 \pm 10,000$ & $90,000 \pm 13,000$ \\
\hline Na-Zr-hybrid & - & $3,700 \pm 310$ & $780 \pm 180$ & $24,000 \pm 12,000$ & $\geq 1,900,000$ & $1,300,000 \pm 380,000$ & $450,000 \pm 110,000$ & $450,000 \pm 12,000$ \\
\hline H-Sn-hybrid & $<1$ & $130 \pm 14$ & $18 \pm 13$ & $140 \pm 4$ & $340,000 \pm 170,000$ & $320,000 \pm 16,000$ & $320,000 \pm 14,000$ & $160,000 \pm 9,100$ \\
\hline Na-Sn-hybrid & - & $260 \pm 57$ & $270 \pm 100$ & $650 \pm 18$ & $480,000 \pm 32,000$ & $300,000 \pm 13,000$ & $220,000 \pm 14,000$ & $220,000 \pm 13,000$ \\
\hline
\end{tabular}

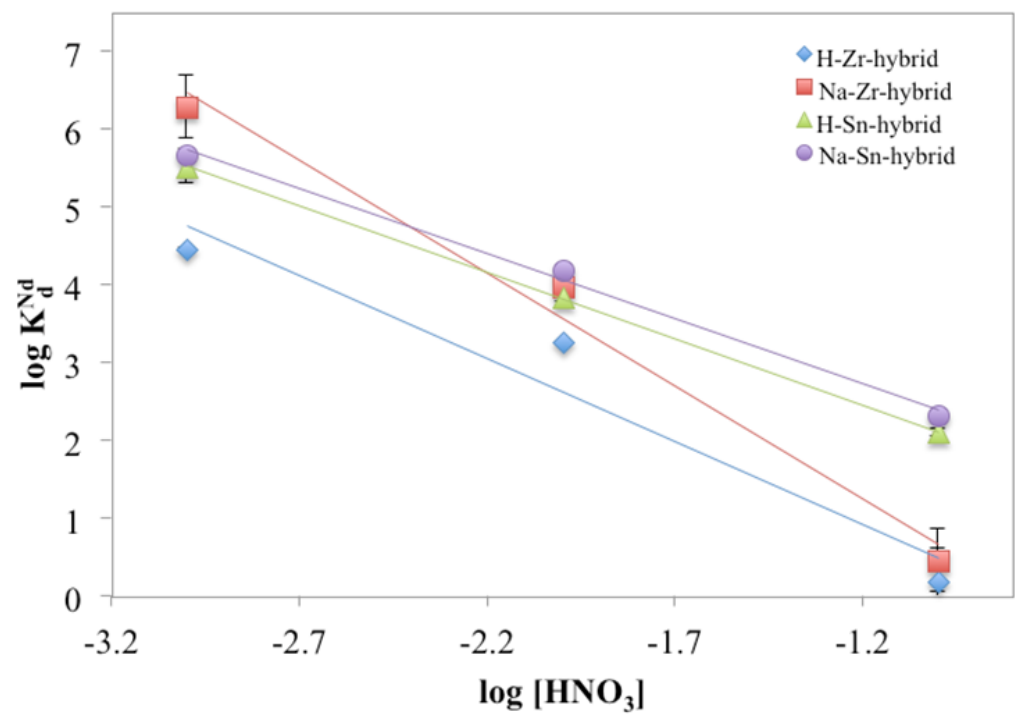

Figure 2: Extraction of $\mathrm{Nd}^{3+}$ as a function of $\left[\mathrm{HNO}_{3}\right]$, the initial $\left[\mathrm{Nd}^{3+}\right]$ was $\sim 10^{-4} \mathrm{M}$. No uptake was observed for $\left[\mathrm{HNO}_{3}\right]>0.1$.

Table 2. $\mathrm{K}_{\mathrm{d}}$ values (mL/g) of Hybrid Zirconium and Tin Phosphonate Ion Exchangers with Selected Actinides and Neodymium in $\mathrm{HNO}_{3}$

\begin{tabular}{ccccc}
$\begin{array}{c}\text { Ion } \\
\text { Exchanger }\end{array}$ & $\begin{array}{c}\mathbf{K}_{\mathbf{d}}\left[\mathbf{N p O}_{2}\right]^{+} \\
\mathbf{p H ~ 2 . 1 1}\end{array}$ & $\begin{array}{c}\mathbf{K}_{\mathbf{d}}\left[\mathbf{P u O}_{2}\right]^{2+} \\
\mathbf{p H ~ 2 . 1 3}\end{array}$ & $\begin{array}{c}\mathbf{K}_{\mathbf{d}} \mathbf{N d}^{3+} \\
\mathbf{p H ~ 2 . 0 5}\end{array}$ & $\begin{array}{c}\mathbf{K}_{\mathbf{d}} \mathbf{P u}^{\mathbf{4}} \\
\mathbf{p H ~ 1 . 7 9}\end{array}$ \\
\hline H-Zr-hybrid & $80 \pm 0$ & $1,400 \pm 5$ & $1,800 \pm 11$ & $1,300 \pm 2$ \\
Na-Zr-hybrid & $3,200 \pm 29$ & $400,000 \pm 3,000$ & $9,800 \pm 760$ & $110,000 \pm 250$ \\
H-Sn-hybrid & $230 \pm 1$ & $3,200 \pm 20$ & $7,000 \pm 420$ & $43,000 \pm 760$ \\
Na-Sn-hybrid & $480 \pm 1$ & $6,100 \pm 19$ & $16,000 \pm 1,200$ & $83,000 \pm 310$
\end{tabular}




\subsection{Electrochemical Separations in Ionic Liquids}

During FY11 we introduced UV/vis/NIR fiber optics into the glovebox containing the electroanalytical equipment, allowing in-situ spectroscopic measurements during polarized conditions and confirmation of higher oxidation states of Am. Experimental results confirmed the formation of Am(IV), however, the formation of Am(IV) does not appear to be the result of direct electrochemical oxidation.

In these experiments Am(III) is introduced as a nitric acid solution, which is evaporated to dryness, followed by the addition of bis(trifluoromethylsulfonyl)imide acid. This mixture is then heated to drive off any remaining nitric acid and water and form the corresponding $\mathrm{N}\left(\mathrm{SO}_{2} \mathrm{CF}_{3}\right)_{2}{ }^{-}$ salt with Am(III). The bis(trifluoromethylsulfonyl)imide is the same anion as in the IL ion pair used in the electrochemical experiments. The experimental findings indicate that some of the nitrate anions remain coordinated to the Am, leaving enough nitrate to affect the chemistry of the system. The reduction of nitrate is observed in the cyclic voltammetry (CV) of 1-butyl-3methylimidazolium bis(trifluoromethyl-sulphonyl)imide, $\left(\left[\mathrm{C}_{4} \mathrm{mim}\right]\left[\mathrm{NTf}_{2}\right]\right.$ ) (see Figure 3), at a potential of about $-1200 \mathrm{mV}$ vs the ferrocene couple $\left(\mathrm{FeCp}_{2} / \mathrm{FeCp}_{2}{ }^{+}\right)$. Also observed in the $\mathrm{CV}$ is the reduction of trace water. To date a completely dry system has not been achieved with our configuration, as it is believed that the inner coordination sphere of water is too tightly bound to Am to be displaced by the weakly coordinating ionic liquid anion. It is the presence of water and nitrate that greatly affected the formation and coordination of the Am(IV).

The reduction of water will yield the formation of the hydroxide $\left(\mathrm{OH}^{-}\right)$ion which will chelate with Am to form $\mathrm{Am}(\mathrm{OH})_{\mathrm{x}}{ }^{3-\mathrm{x}}$ species. $\mathrm{Am}(\mathrm{OH})_{\mathrm{x}}{ }^{3-\mathrm{x}}$ species have been well studied and $\mathrm{Am}(\mathrm{OH})^{2+}$ is known to have an absorption peak at $521 \mathrm{~nm}$ (see Figure 4). This peak appears as a shoulder to the Am(III) peak at $503 \mathrm{~nm}$. The reduction of nitrate produces not only additional hydroxide, but it also produces dinitrogen tetraoxide $\left(\mathrm{N}_{2} \mathrm{O}_{4}\right)$ as shown in equation 1 .

$2 \mathrm{NO}_{3}^{-}+\mathrm{H}_{2} \mathrm{O}+2 \mathrm{e}^{-} \rightarrow \mathrm{N}_{2} \mathrm{O}_{4}+4 \mathrm{OH}^{-} \quad \mathrm{E}^{\mathrm{o}}=-0.85 \mathrm{~V}$ eq 1

$\mathrm{N}_{2} \mathrm{O}_{4}$ is a very strong oxidizer, and from electrochemical formation in-situ, we postulate that it oxidized some of the Am(III) to Am(IV), characterized by the ingrowth of the $456 \mathrm{~nm}$ peak (see Figure 5). The molar absorptivity of the $456 \mathrm{~nm}$ peak is $\sim 15 \mathrm{x}$ weaker than the $503 \mathrm{~nm}$ peak for $\mathrm{Am}(\mathrm{III})$, but the UV/vis provides direct confirmation of the production of Am(IV). Further testing using chemically generated $\mathrm{N}_{2} \mathrm{O}_{4}$, from nitric acid reacting with $\mathrm{Cu}^{\circ}$, did not produce $\mathrm{Am}(\mathrm{IV})$, but this could be an artifact of the method of introducing the $\mathrm{N}_{2} \mathrm{O}_{4}$ into the reactor. The chemically produced $\mathrm{N}_{2} \mathrm{O}_{4}$ gas was bubbled through the ionic liquid with $\mathrm{Am}$ (III), but without a gas diffuser small enough to fit within the $1 \mathrm{~cm} \mathrm{UV/vis} \mathrm{cell} \mathrm{the} \mathrm{configuration} \mathrm{resulted} \mathrm{in} \mathrm{large} \mathrm{gas}$ bubbles with limited surface area that diffused into the ionic liquid. In contrast, the electrochemically generated $\mathrm{N}_{2} \mathrm{O}_{4}$ was generated at the surface of a Pt mesh and formed small bubbles that could react readily with Am(III).

Tests explored the effects of adding complexing agents on the electrochemical oxidation of Am(III). In addition to removing electrochemical active bound water, complexation of the Am(III) should also decrease the oxidation potential of the Am(III) through a change in coordination environment. However, in all experiments we observed no evidence that addition of strong organic ligands (e.g., diethylenetriamine-N,N,N',N",N"'-pentaacetic acid (DTPA)) influenced the oxidation potential resulting in the direct electrochemical oxidation of Am(III) to Am(IV). The addition of carbonate, a strong chelating inorganic ligand in aqueous solutions, also proved unsuccessful. 


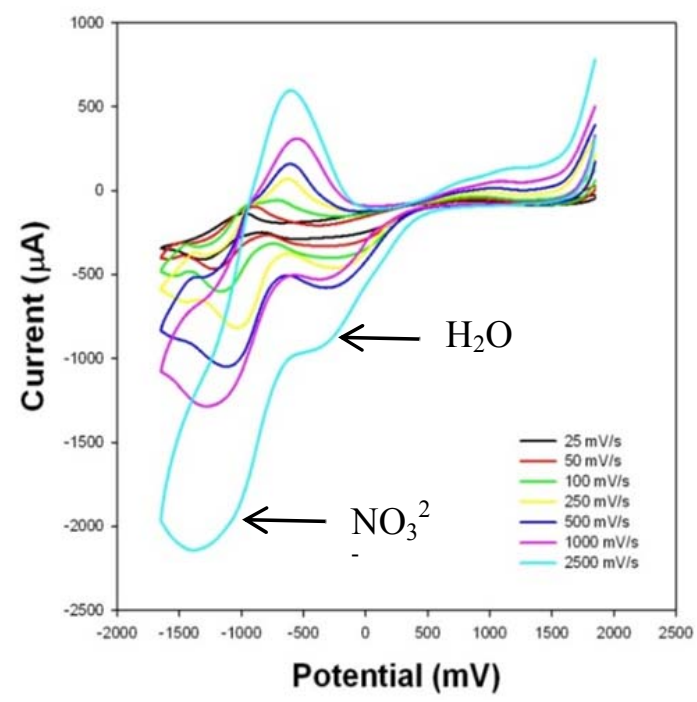

Figure 3: Cyclic voltammetry of $\mathrm{Am}\left(\mathrm{NTf}_{2}\right)_{\mathrm{x}}\left(\mathrm{NO}_{3}\right)_{\mathrm{y}}$ in $\left[\mathrm{C}_{4} \mathrm{mim}\right]\left[\mathrm{NTf}_{2}\right]$ at various scan rates, $\mathrm{Pt} / \mathrm{Pt} / \mathrm{Pt}$, $\mathrm{FeCp}_{2} / \mathrm{FeCp}_{2}{ }^{+}=0.0 \mathrm{~V}$.

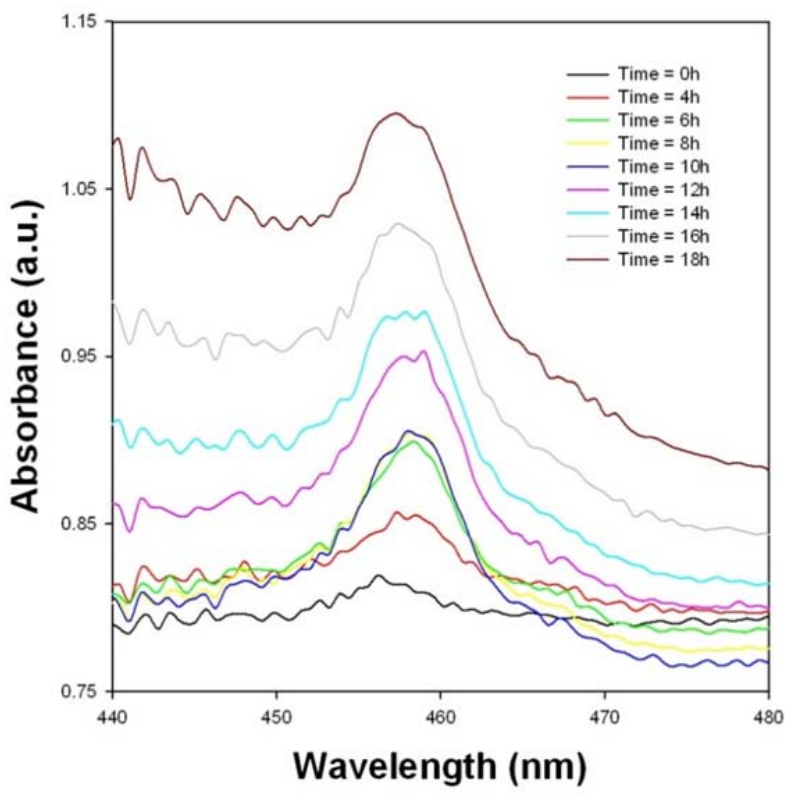

Figure 5: The formation of Am(IV) through the reduction of $\mathrm{NO}_{3}{ }^{2-}$ forming in-situ $\mathrm{N}_{2} \mathrm{O}_{4}$.

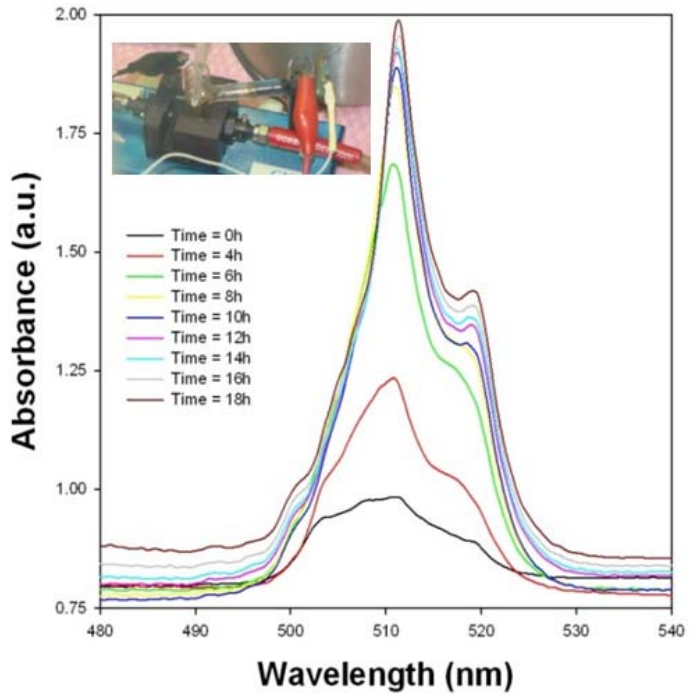

Figure 4: The formation of $\operatorname{Am}(\mathrm{OH})^{2+}$ through electrochemical reduction of trace $\mathrm{H}_{2} \mathrm{O}$. 


\section{REFERENCES}

1. Zagorodni, A. Z. Ion Exchange Materials - Properties and Applications, Elsevier, Amsterdam, 2007.

2. "Structural and ion exchange properties of nanocrystalline Si-doped antimony pyrochlore", V. Luca, V.; Griffith, C. S.; Blackford, M. G.; Hanna, J. V. J. Mater. Chem. 2005, 15, 564-572.

3. "Use of silicotitanates for removing cesium and strontium from defense waste", Anthony, R. G.; Dosch, R. G.; Gu, Ding; Philip, C. V. Industrial \& Engineering Chemistry Research 1994, 33(11), 2702-2705.

4. "Strontium and actinide separations from high level nuclear waste solutions using monosodium titanate 1. simulant testing", Hobbs, D. T.; Barnes, M. J.; Pulmano, R. L.; Marshall, K. M.; Edwards, T. B.; Bronikowski, M.G.; Fink, S. D.; Separation Science and Techology, 2005, 40(15), 3093-3111.

5. "A family of peroxo-titanate materials tailored for optimal strontium and actinide sorption," Nyman, M. D.; Hobbs, D. T. Chemistry of Materials, 2006, 18, 6425 - 6435.

6. "Sorption Behavior of Monosodium Titanate and Amorphous Peroxotitanate Materials under Weakly Acidic Conditions," Elvington, M.C.; Click, D.R.; Hobbs, D.T. Separation Science and Technology, 2010, 45, 66 - 72.

7. Krauskopf, K. B. Chem. Geol. 1986, 55, 323.

8. Dupouy, G.; Bonhoure, I.; Conradson, S. D.; Dumas, T.; Hennig, C.; Le Naour, C.; Moisy, P.; Petit, S.; Scheinost, A. C.; Simoni, E.; Den Auwer, C. European Journal of Inorganic Chemistry 2011, 2011, 1560.

\section{INDICATORS OF PROJECT QUALITY AND PRODUCTIVITY}

\section{Journal Publications}

"Separation of americium and lanthanides using titanium-based materials", Elvington, M.C.; Shehee, T.C.; Rudisill T.S. and Hobbs, D. T.; Solvent Extraction and Ion Exchange, accepted for publication.

"Pillared Metal(IV) Phosphate-Phosphonate Extraction of Actinides", Burns, J.; Clearfield, A.; Borkowski, M.; Reed, D.; Radiochimica Acta, submitted.

\section{Presentations}

"Development of Pillared M(IV) Phosphonate Phosphate Materials for Lanthanide-Actinide Separations" Jonathan Burns and Abraham Clearfield, (Texas A\&M University), presented at the 35th Annual Actinide Separations Conference, Charlotte, NC, May 23-27, 2011.

"The Use of Ionic Liquids as an Electrochemical Media for the Oxidation of Americium", N. J. Bridges, A. E. Visser, D.T. Hobbs, (SRNL), presented at the 35th Annual Actinide Separations Conference, Charlotte, NC, May 23-27, 2011.

"Minor Actinide Separations using Ion Exchangers", T. C. Shehee and D.T. Hobbs, (SRNL), presented at the 35th Annual Actinide Separations Conference, Charlotte, NC, May 23-27, 2011. 
"Development of Pillared M(IV) Phosphonate Phosphate Materials for Applications in Separations", Jonathan Burns, presented at the Inorganic Chemistry Department Seminar, Texas A\&M University, College Station, TX, 77842, May, 18, 2011.

"Unconventional Layered Porous Pillared Metal Phosphonates", Abraham Clearfield; Jonathan D. Burns; Tiffany Kinnibrugh; Atashi Mukherjee; Houston P. Perry; Kevin Gagnon; Nancy Garcia; Zachary Beal, (Texas A\&M University), presented at the 43rd World Chemistry Congress IUPAC 2011, San Juan, Puerto Rico July 30- August 5, 2011.

"Actinide Separations under Acidic Conditions," T.C. Shehee and D.T. Hobbs, (SRNL), presented at the $242^{\text {nd }}$ National Meeting of the American Chemical Society, Denver, CO, August 27 - September 1, 2011.

\section{Other activities}

Prof. Abraham Clearfield was nominated for the International Eni Prize in the category, Protection of the Environment.

Prof. Abraham Clearfield organized the symposium, Layered Materials from Nanoparticles to Bioplatforms, at the 43rd World Chemistry Congress IUPAC 2011, San Juan, Puerto Rico July 30 - August 5, 2011.

D.T. Hobbs served as a panelist for the Speciation and Chemistry of Actinides and Key Fission Products and A. Clearfield served as a participant for the Design of Molecules and Materials with Selective Separation Properties at the DOE NE/EM/NNSA Workshop, Nuclear Separations Technologies, held in Betheseda, MD on July $27-28,2011$.

D.T. Hobbs coorganized the 3-day symposium, "Analytical Methods in Nuclear Technology", at the $242^{\text {nd }}$ National Meeting of the American Chemical Society in Denver, CO, August 28 September 1, 2011.

\section{COLLABORATORS AND PARTICIPANTS}

Participants in the ion-exchange research include Dr. David Hobbs (SRNL), Dr. Thomas Shehee, postdoctoral researcher (SRNL), Prof. Abraham Clearfield, (TAMU), Jonathan Burns and Tiffany Kinnibrugh, graduate students (TAMU), and Sean Springer and Faisal Alshafei, undergraduate students (TAMU). Dr. Don Reed and Dr. Marian Borkowski of Los Alamos National Laboratory in Carlsbad, NM are unfunded collaborators who provided laboratory facilities and actinide materials to J. Burns (TAMU) for the measurement of ion-exchange performance of the hybrid materials. Prof. Linda Wang and Lei Ling, graduate student (Purdue University) are collaborators that are funded by Argonne National Laboratory and provide guidance and assistance in the development of performance models of ion-exchange materials. Dr. Ann Visser (SRNL) and Dr. Nicholas Bridges (SRNL) lead the experimental studies investigating the electrochemistry of americium in ionic liquids. 